J. Clin. Chem. Clin. Biochem.

Vol. 19, 1981, pp. 371-374

\title{
Bilirubin Adsorption In Vitro by Foetal and Adult Human Erythrocytes
}

\author{
By Inés Ana Gioia*, Raquel E. Serrani* and J. L. Corchs** \\ Depto. de Ciencias Fisiológicas, Fisiologia, Fac. Cs. Médicas, Universidad Nacional de Rosario. \\ Santa Fe 3100, Rosario, 2000. Argentina \\ * Miembro de la Carrera de Investigador. Universidad Nacional de Rosario. Argentina. \\ ** Profesor Titular. Cátedra de Fisiologia. Miembro de la Carrera de Investigador. Consejo Nacional de Investigaciones Cientificas y \\ Técnicas. Argentina.
}

(Received May 16, 1980/January 5, 1981)

Summary: Adsorption of bilinubin in vitro by human foetal erythrocytes from umbilical cords was significantly greater than the binding by adult erythrocytes.

A difference in binding capacity was detected at $0.6 \mathrm{mmol} / \mathrm{l}$ bilirubin concentration (bilirubin/albumin ratio $2: 1$ ) immediately after mixing with the bilirubin solution.

After $30 \mathrm{~min}$ incubation a further increase in bound bilirubin was found to be due only to binding in foetal cells.

The results suggest that bilirubin from the medium was incorporated into at least two compartments in foetal erythrocytes.

A possible role of human foetal erythrocytes in bilirubin distribution to tissues is stressed.

\section{Adsorption von Bilirubin in vitro an foetale und adulte Erythrocyten des Menschen}

Zusammenfassung: Die Adsorption von Bilirubin in vitro durch foetale menschliche Erythrocyten aus dem Blut der Nabelschnur war bedeutend größer als die durch Erythrocyten von Erwachsenen. Dieser Unterschied konnte bei einer Bilirubinkonzentration von $0,6 \mathrm{mmol} / 1$ im Inkubationsmedium (einer Lösung von Albumin, Verhältnis Bilirubin/ Albumin 2:1) unmittelbar nach dem Suspendieren des Blutes in der Bilirubinlösung festgestellt werden.

Nach 30 Minuten Inkubationszeit bei $37^{\circ} \mathrm{C}$ erhöhte sich nur die Adsorption von Bilirubin an foetale Erythrocyten signifikant, während man im Gegenteil keine Veränderungen beim Bilirubin in Gegenwart der roten Blutkörperchen Erwachsener beobachten konnte. Die Ergebnisse deuten darauf hin, daß das Bilirubin des Inkubationsmediums in zwei Kompartimente der foetalen Erythrocyten aufgenommen wird. Die mögliche Rolle foetaler Erythrocyten bei der Verteilung des freien Bilirubins in den Geweben wäre demzufolge zu beachten.

\section{Introduction}

Studies on the interaction of bilirubin with substances in the bloodstream show that bilinubin has a great affinity for albumin; two molecules of bilirubin bind with one molecule of albumin in such a way that one bilirubin molecule is much more firmly bound than the other (1-3). In addition to binding with albumin, bilirubin is bound by erythrocytes (4-9). Bilirubin binding by erythrocytes may play a role in bilirubin toxicity in newborn $(10-12)$. We found previously that erythrocytes from newborn rats have a greater capacity than erythrocytes from adult rats to bind bilirubin (13). The present study was carried out to extend our studies on bilirubin binding to human erythrocytes and to determine whether there are differences between foetal and adult erythrocytes in bilirubin binding.

\section{Material and Methods \\ Preparation of cell suspensions}

Blood from normal human adults and from the umbilical cords of normal human newborns were used with heparin as anticoagulant. Erythrocy tes were separated by centrifugation $(1400 \mathrm{~g}, 5 \mathrm{~min})$. The upper layer of packed cells rich in leucocy tes was discarded. The cells were washed with Ringer-Krebs solution (see below) by resuspension in ten times their volume. The cells were used either within $2 \mathrm{~h}$ after collection or stored at $4^{\circ} \mathrm{C}$ in a Ringer-Krebs solution for use within $24 \mathrm{~h}$ after collection (9). Samples which showed haemolysis were discarded. The erythrocyte stroma was prepared by the method of Tiscoff (14). 


\section{Preparation of bilinubin solutions}

Unconjugated bilirubin was dissolved in $0.1-0.15 \mathrm{ml} \mathrm{NaOH}$ $(0.1 \mathrm{~mol} / \mathrm{l})$ and then added to Ringer-Krebs of the following composition (mmol/l): $\mathrm{NaCl} 140 ; \mathrm{KCl} 4.9 ; \mathrm{CaCl}_{2}$ 0.25; $\mathrm{NaH}_{2} \mathrm{PO}_{4} 1.5 ; \mathrm{Na}_{2} \mathrm{HPO}_{4} 6.9 ; \mathrm{MgSO}_{4} 1.2 ;$ glucose 11 (pH 7.4) (15) containing bovine serum albumin to give a molar ratio of bilirubin to albumin of 2:1 (bilirubin-albumin solution). Bilirubin solutions in the concentration range $100-820 \mu \mathrm{mol} / 1$ were prepared.

\section{Incubation procedures}

The incubation mixture consisted of $0.5 \mathrm{ml}$ bilirubin-albumin solution and $1 \mathrm{ml}$ red cell suspension of haematocrit 0.50 . In order to estimate the quantity of bilirubin bound by cells two procedures ( $a$ and $b$, below) were used.

(a) $(16,17,18)$ Immediately after mixing with the bilirubinalbumin solution (or in some experiments, after an incubation period at $37^{\circ} \mathrm{C}$ in a shaking bath) the cells were packed by centrifugation and bilirubin was determined in the supernatant.

Simultaneously and in similar conditions the bilirubin concentration was measured in a control tube of the same solution without the addition of red cells, to take account of the spontaneous loss of bilirubin.

The decrease of bilirubin in the medium surrounding the cells, related to the control tube, was interpreted as a measure of its binding by the cells.

(b) $(5,6)$ After 15 min incubation with bilirubin-albumin solution the red cell suspension was centrifuged for $5 \mathrm{~min}$ (at about $1000 \mathrm{~g}$ ) and the supernatant was discarded. Then, the red cells were washed three times in $40 \mathrm{ml}$ of the Ringer-Krebs solution until no yellow colour was seen in the washings. After the final washing, the supernatant was discarded and the cells were resuspended in $2 \mathrm{ml}$ of $30 \mathrm{~g} / \mathrm{l}$ of bovine serum albumin, $\mathrm{pH} 7.4$. The red cell suspension was incubated in a shaking water bath for $15 \mathrm{~min}$ at $37^{\circ} \mathrm{C}$ and the bilirubin bound by cells was eluted.

After sedimenting the cells by centrifugation, the bilirubin concentration was determined in the supernatant and the amount of bilirubin bound by cells was calculated. As $95 \%$ of the elutable bilirubin was consistently removed in the first eluate, only a single elution was performed $(5,6,8)$.

All the experiments were carried out in the dark. The $\mathrm{pH}$ of the medium was unchanged after incubation.

\section{Recovery of bilirubin added to the system (cells plus medium)}

It was determined by comparing the quantity of bilirubin in the stroma of ery throcy tes incubated in a bilirubin-albumin solution plus that in the supernatant, with the quantity measured in the suspension of the same stroma (18).

\section{Analytical procedures}

The bilirubin concentration in the supernatant was estimated by direct spectrophotometry $(1,17)$ in a Beckman DU 2 Spectrophotometer $(460 \mathrm{~nm})$. A correction was made for the interference due to haemoglobin (19). The results did not differ from those obtained by the diazo reaction (20) for bilirubin determination.

The amount taken up by the cells was expressed as $\mu$ inol $/ 1$ cells. Haematological studies included the determination of the packed cell volume and immature cell counts in blood smears by standard laboratory techniques (21). Reticulocy tes and other immature cells amounted to no more than $2 \%$ in all the samples studied.

\section{Chemicals}

Bilirubin and bovine serum albumin were obtained from Sigma (St. Louis Mo., U.S.A.). All other reagents used were of analy tical grade.

\section{Results}

Spontaneous disappearance of bilirubin in the incubation medium during $30 \mathrm{~min}$ of incubation averaged $2.3 \%$ (fig. 1). Recovery of bilirubin averaged $95 \%$.

Table 1 shows the data on in vitro bilirubin binding by foetal and adult erythrocytes. Significantly more bilirubin was bound immediately at a bilirubin concentration of $600 \mu \mathrm{mol} / 1$ than at a concentration of $300 \mu \mathrm{mol} / 1$ by foetal and adult erythrocytes $(p<0.001$ and 0.02 , respectively). Foetal and adult erythrocytes showed no significant difference in the immediate binding of bili-

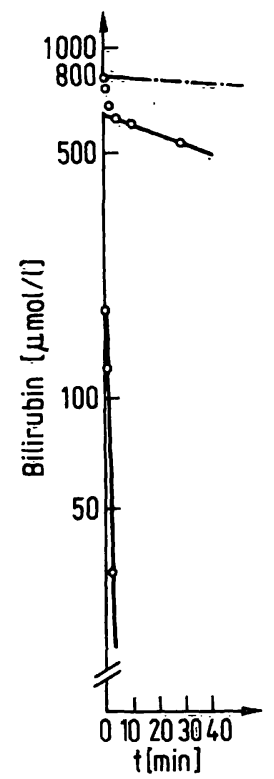

Fig. 1. Semilogarithmic plot showing the disappearence of bilirubin from the incubation medium $(\mu \mathrm{mol} / \mathrm{l})$ during in vitro studies on human foetal ery throcytes. Foetal ery throcy tes from umbilical cords were suspended in a bilirubin solution with an initial concentration of $820 \mu \mathrm{mol} / \mathrm{l}$. Also shown is the "spontaneous dissappearence" of bilirubin from the incubation medium in the absence of erythrocytes (dot-dash lines) (see Methods). Each point (upper set) corresponds to the mean \pm S.E.M. (included in the symbols) of four determinations. The lines were fitted to the points by eye.

Tab. 1. The effects of the bilirubin concentration in the medium and of the incubation time on in vitro bilirubin binding by foetal and adult human erythrocy tes values are mean \pm S.E.M. for the number of individual samples shown in parenthesis.

\begin{tabular}{|c|c|c|c|}
\hline $\begin{array}{l}\text { Bilirubin } \\
\text { concen- } \\
\text { tration } \\
\text { (mmol/1) }\end{array}$ & $\begin{array}{l}\text { Incuba- } \\
\text { tion } \\
\text { time } \\
\text { (min) }\end{array}$ & $\begin{array}{l}\text { Bilirubin binding } \\
\text { ( } \mu \text { mol/l cells) } \\
\text { Adult ery throcytes }\end{array}$ & Foetal erythrocy tes \\
\hline $\begin{array}{l}0.3 \\
0.6 \\
0.6\end{array}$ & $\begin{array}{r}0 \\
0 \\
30\end{array}$ & $\begin{array}{l}274 \pm 13(21) \\
\left.317 \pm 11(16)^{b}\right) \\
346 \pm 8(5)\end{array}$ & $\begin{array}{l}241 \pm 30 \quad(9) \\
\left.\left.413 \pm 26(10)^{\mathrm{a}}\right)^{\mathrm{b}}\right) \\
\left.\left.723 \pm 42 \quad(9)^{\mathrm{a}}\right)^{\mathrm{c}}\right)\end{array}$ \\
\hline
\end{tabular}

a) significantly greater than corresponding adult value.

b) significantly greater than corresponding $0.3 \mathrm{mmol} / 1$ value.

c) significantly greater than corresponding $0.6 \mathrm{mmol} / \mathrm{i}$ with 0 incubation time. 
rubin at a bilirubin concentration of $300 \mu \mathrm{mol} / 1$, while a significant difference was observed at a bilirubin concentration of $600 \mu \mathrm{mol} / 1(\mathrm{p}<0.01)$.

After $30 \mathrm{~min}$ of incubation at a bilirubin concentration of $600 \mu \mathrm{mol} / 1$, bilirubin binding increased significantly compared with immediate bilirubin, and this increase occurred only in the foetal erythrocytes $(p<0.001)$. After 30 min of incubation at a bilirubin concentration of $600 \mu \mathrm{mol} / 1$ the difference between bilirubin bound by foetal and adult erythrocytes was highly significant $(\mathrm{p}<0,001)$.

Figure 1 shows a semilogarithmic plot (22) of the data on the disappearance of bilirubin from the incubation medium in the presence of foetal erythrocytes. The concentration of bilirubin in the medium decreased with time. Two linear functions fitted the data, which correspond to a fast component with a rate constant of $0.3 \mathrm{~min}^{-1}$ and a slow component with a rate constant of $0.04 \mathrm{~min}^{-1}$. Bilirubin bound to adult and foetal erythrocytes during a $15 \mathrm{~min}$ incubation period was partially eluted when the cells were incubated with a concentrated $30 \mathrm{~g} / 1$ albumin solution for a further $15 \mathrm{~min}$ period (see legends to fig. 2 and 3 ).

Before albumin elution, the plot of bilirubin bound by adult cells as a function of its concentration in the medium differed in slope $(p<0.001)$ from that for foetal cells (unfilled circles, figs. 2 and 3). In both types of cells, the slope corresponding to data obtained previous to albumin elution (unfilled circles, fig. 2 and

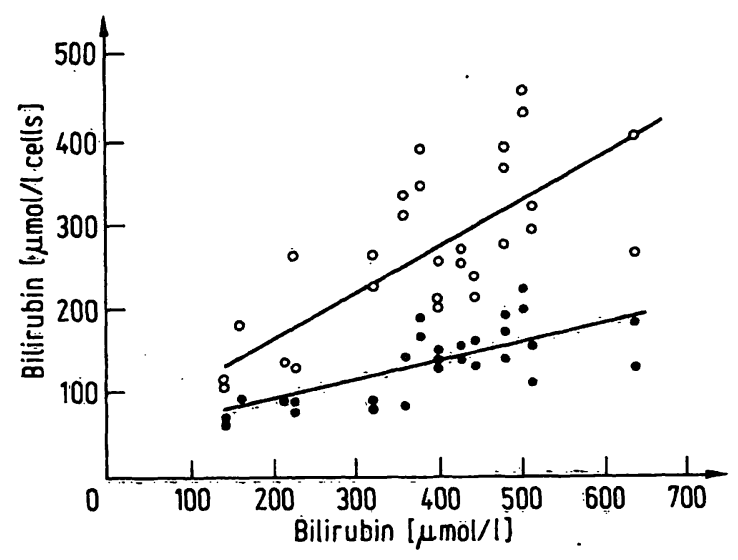

Fig. 2. Bilirubin bound by adult human erythrocytes. Each sample was successively submitted to procedures described in Material and Methods under (a) and (b), which correspond to unfilled and filled circles respectively. The initial concentration of Bilirubin in the medium appears on the abscissa and the amount of bilirubin bound by cells appears on the ordinate. Duplicate determination at each concentration and' by both procedures are presented. Lineal functions (data were fitted by the least squares method) describe bilirubin binding (as a function of medium bilirubin concentration) estimated before $(a=97.4, b=442.6 n=28$ - unfilled circles - ) and after $(a=57.4, b=194 n=29-$ filled circles -$)$ albumin elution. The difference between the slope of the curves was significant $(\mathrm{p}<0.05)$.

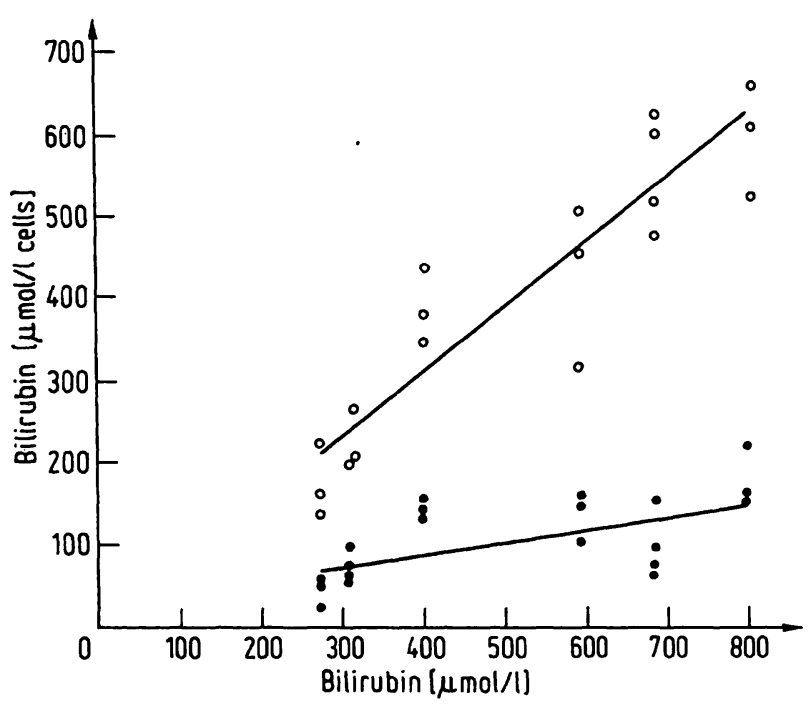

Fig. 3. Same procedures as in fig. 2 but in foetal erythrocytes. Lineal functions (data were fitted by the least squares method) describe bilirubin binding (as a function of medium bilirubin concentration) estimated before $(\mathrm{a}=9.52, \mathrm{~b}=790.53, \mathrm{n}=20-$ unfilled circles - ) and after $(\mathrm{a}=22.49, \mathrm{~b}=172.14, \mathrm{n}=20$ - filled circles - ) albumin elution. The difference between slopes was significant $(p \ll 0.001)$.

fig. 3), differed from the slope corresponding to data obtained after albumin elution (filled circles, same figures) ( $\mathrm{p}<0.05$ for adult and $\mathrm{p} \ll 0.001$ for foetal cells).

\section{Discussion}

The present findings show that the capacity to bind bilirubin in vitro is greater, per unit of packed erythrocyte volume, in foetal than in adult erythrocytes.

Differences in surface area/volume ratio (23) between both cells could not explain the differences in bilirubin binding which would be even greater than those presented if binding were expressed per unit of cell surface area.

It is to be noted that changes in metabolic and membrane functions (24-27) have been reported to occur in red blood cells during the postnatal period.

The slow component of bilirubin concentration decay in a medium with suspended foetal cells (fig. 1) would represent bilirubin incorporation into a compartment which was not observed in cells from adults. This is related to the significant increase observed in bilirubin bound by foetal cells on incubation (tab. 1). The pigment bound to both types of cells was partially eluted by albumin (figs. 2 and 3 ) although the fraction eluted was significantly greater in adult than in to foetal cells. This finding points to differences in bilirubin affinity of cell surface sites.

The difference in bilirubin binding capacity between both cell types, although evident at a medium bilirubin 
concentration equal to twice the plasma bilirubin concentration when exchange transfusion is indicated, would suggest a possible role of circulating foetal red cells in bilirubin distribution to the tissues. This would be of the greatest interest during the neonatal period.

\section{Acknowledgements}

We appreciate the technical assistance of Mrs. Beatriz Pérez and Mr. Héctor Hugo Berra. This work was supported by a grant from the Consejo Nacional de Investigaciones Científicas y Técnicas, República Argentina.

\section{References}

1. Coutinho, C. B., Lucek, R. W., Cheripko, J. A. \& Kuntzman, R. (1973), Ann. N. Y. Acad. Sciences 226, 238-246.

2. Jacobsen, J. (1969), FEBS Letters 5, 112-114.

3. Schmid, R., Diamond, S., Hammaker, L. \& Gundersen, C. (1965), Nature 206, 1041-1043.

4. Barnhart, J. L. \& Clarenburg, R. (1973), Proc. Soc. Exp. Med. 142, 1101-1103.

5. Bratlid, D. (1972), Scand. J. Clin. Lab. Invest. 29, 91-97.

6. Bratlid, D. (1972), Scand. J. Clin. Lab. Invest. 29, 453459.

7. Kapoor, C. (1975), Curr. Sci. 44, 82-84.

8. Kaufman, N., Simcha, A. \& Blondheim, S. (1967), Clin. Sci. 33, 201-208.

9. Oski, F. \& Naiman, J. (1963), J. Pediat. 63, 1034-1037.

10. Blanc, W. A. \& Johnson, L. (1959), J. Neuropathol. Exp. Neurol. 18, 165-189.

11. Rozdilsky, B. \& Olszewski, J. (1961), J. Neuropathol. Exper. Neurol. 20, 193-205.

12. Silbergerg, D., Johnson, L., Shutta, H. \& Ritter, L. (1970), J. Pediat. 77, 613-617.

13. Corchs, J. L., Serrani, R. \& Gioia, I. (1978), Medicina (Bs. As.) 38, 176-181.

14. Tishkoff, G. H., Robscheit-Roblins, F. \& Whipple, G. (1953), Blood 8, 459-468.

15. Reisin, I., Rotunno, C., Corchs, J. L., Kowalewky, V. \& Cereijido, M. (1970), Physiol. Chem. Phys. 2, 171-179.

16. Schaklai, M., Yguerabide, H. \& Ranney, H. (1977), Biochemistry 16, 5593-5597.

17. Nelson, T., Jacobsen, J. \& Wennberg, R. (1974), Pediat. Res. 8, 963-967.

18. Odell, G. (1966), J. Pediat. 68, 164-180.

19. Najjar, V. (1952), Pediatrics 10, 1-10.

20. Malloy, H. \& Evelyn, K. (1937), J. Biol. Chem. 119, 481 490.

21. Dacie, H. \& Lewis, S. (1970), Practical Haematology. (Fourth ed. J. and Churchill Ltd., Longman Group, Ltd. London).

22. Riggs, D. (1963), The Mathematical Approach to Physiological Problems. (The Williams and Wilkins Company, Waverly Press, Baltimơre).

23. Oski, F. \& Naiman, L. (1968), Problemas hematológicos en el recién nacido ( $2^{\circ}$ ed. Edit. Científico-Médica, Barcelona).

24. Crowley, J., Ways, P. \& Jones, J. (1965), J. Clin. Invest. 44, 989-997.

25. Widdas, W. (1951), J. Physiol. 113, 399-411.

26. Blechner, J. N. (1961), Am̄. J. Physiol. 201, 85-88.

27. Blostein, R., Whittington, E. S. \& Kuebler, E. (1974), Ann. N. Y. Acad. Sci. 242, 305-315.
Dr. J. L. Corchs Av. Francia 2468 2000-Rosario República Argentina 